\title{
Long-term balanced fertilization increases the soil microbial functional diversity in a phosphorus-limited paddy soil
}

\author{
JIAN-QIANG SU, ${ }^{* 1}$ LONG-JUN DING,$\uparrow^{1}$ KAI XUE, + HUAI-YING YAO,$*$ JOHN QUENSEN,

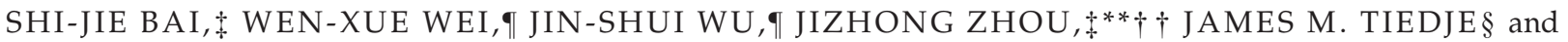 \\ YONG-GUAN ZHU*† \\ *Key Lab of Urban Environment and Health, Institute of Urban Environment, Chinese Academy of Sciences, Xiamen 361021 , \\ China, $\uparrow$ State Key Lab of Urban and Regional Ecology, Research Center for Eco-environmental Sciences, Chinese Academy of \\ Sciences, Beijing 100085, China, \$Department of Microbiology and Plant Biology, Institute for Environmental Genomics, \\ University of Oklahoma, 101 David L Boren Blvd, Norman, OK 73019, USA, §Center for Microbial Ecology, Department of \\ Plant, Soil and Microbial Sciences, Michigan State University, East Lansing, MI 48824, USA, ๆKey Laboratory of Agro- \\ ecological Processes in Subtropical Regions and Taoyuan Station of Agro-ecology Research, Institute of Subtropical Agriculture, \\ Chinese Academy of Sciences, Changsha 410125, China, ${ }^{* *}$ Earth Science Division, Lawrence Berkeley National Laboratory, \\ Berkeley, CA 94720, USA, ††State Key Joint Laboratory of Environment Simulation and Pollution Control, School of \\ Environment, Tsinghua University, Beijing 100084, China
}

\begin{abstract}
The influence of long-term chemical fertilization on soil microbial communities has been one of the frontier topics of agricultural and environmental sciences and is critical for linking soil microbial flora with soil functions. In this study, 16S rRNA gene pyrosequencing and a functional gene array, GEOCHIP 4.0, were used to investigate the shifts in microbial composition and functional gene structure in paddy soils with different fertilization treatments over a 22-year period. These included a control without fertilizers; chemical nitrogen fertilizer (N); $N$ and phosphate (NP); $N$ and potassium (NK); and N, P and K (NPK). Based on 16S rRNA gene data, both species evenness and key genera were affected by $P$ fertilization. Functional gene array-based analysis revealed that long-term fertilization significantly changed the overall microbial functional structures. Chemical fertilization significantly increased the diversity and abundance of most genes involved in C, N, P and S cycling, especially for the treatments NK and NPK. Significant correlations were found among functional gene structure and abundance, related soil enzymatic activities and rice yield, suggesting that a fertilizerinduced shift in the microbial community may accelerate the nutrient turnover in soil, which in turn influenced rice growth. The effect of $\mathbf{N}$ fertilization on soil microbial functional genes was mitigated by the addition of $P$ fertilizer in this P-limited paddy soil, suggesting that balanced chemical fertilization is beneficial to the soil microbial community and its functions.
\end{abstract}

Keywords: 16S rRNA gene pyrosequencing, chemical fertilizer, GEOCHIP, long-term fertilization, soil microbial community

Received 29 August 2014; revision received 13 November 2014; accepted 17 November 2014

Correspondence: Yong-Guan Zhu, Fax: 86592 6190977;

E-mail: ygzhu@iue.ac.cn

${ }^{1}$ These two authors contributed equally to this work.

\section{Introduction}

Rice is an important staple food feeding more than half of the world's population. Chemical and organic fertilizers are commonly used in rice cultivation to increase 
rice yields and meet the demand from an ever-expanding population. The highly diverse and abundant soil microbes are central to nutrient cycling, hence soil fertility, and ultimately the productivity, diversity and composition of plant communities (van der Heijden et al. 2008). Application of chemical fertilizers, nitrogen $(\mathrm{N})$, phosphorus (P) and potassium (K), increases nutrient availability to rice and may also alter soil productivity through changing microbial community structure and function. Due to the worldwide application of chemical fertilizers in agricultural fields, the impacts of long-term $\mathrm{N}, \mathrm{P}$ and $\mathrm{K}$ inputs on soil microorganisms and biogeochemical cycling have been the focus of many studies (Fierer et al. 2012; Ramirez et al. 2012; Lentendu et al. 2014).

Organic fertilizers, including plant residue, animal manure and composted organic matter, usually increase soil microbial biomass, activity and diversity (Saunders et al. 2012; Zhang et al. 2012). However, the impacts of chemical fertilizers or different management regimes on the soil microbial community structure and function remain uncertain, and the underlying mechanisms have not been fully explored. Long-term chemical fertilization increased microbial biomass and activities, as measured by PCR-DGGE, PLFA analysis and communitylevel catabolic profiles (Biolog), without significantly changing bacterial community structure (Chu et al. 2007; Islam et al. 2011; Zhang et al. 2012), while another study revealed that it decreased arbuscular mycorrhizal fungal diversity as determined by pyrosequencing (Lin et al. 2012).

The influence of $\mathrm{N}$ addition on the soil microbial community has received extensive study. Added $\mathrm{N}$ has been shown to have important impacts on bacterial, archaeal and fungal communities across ecosystems (Campbell et al. 2010; Wessén et al. 2010; Gorfer et al. 2011). Although it is well established that $\mathrm{N}$ input significantly influences specific $\mathrm{N}$-cycling processes and associated microbes (He et al. 2007; Gorfer et al. 2011; Lu et al. 2011), the impacts of $\mathrm{N}$ or balanced fertilizers on the overall below-ground microbial community dynamics and other biogeochemical processes remained largely unknown. Using 454 pyrosequencing and shotgun metagenomic sequencing, Fierer et al. (2012) found significant shifts in microbial composition and a correlation between catabolic activities and phylogenetic and metagenomic responses across $\mathrm{N}$ gradient. However, we know less about the responses of microorganisms to nutrient $(\mathrm{P}$ or $\mathrm{K}$ ) deficiency or balanced fertilization practices.

To gain a more comprehensive understanding of the impacts of different fertilization regimes on the soil microbial communities, 454 pyrosequencing and GEOCHIP analysis were used to examine differences in microbial and functional gene structures among experimental sites managed for 22 years with different chemical fertilizer treatments. Also, the soil enzyme activities were investigated to reveal possible linkages between microbial composition and function. Our hypothesis is that (i) long-term chemical fertilization would change the microbial community composition and functional gene structure, and (ii) chemical fertilizers could enhance C-, $\mathrm{N}$ - and P-cycling genes, hence stimulated soil nutrient turnover and rice yield.

\section{Materials and methods}

\section{Soil sampling}

The long-term fertilizer experiment site was located at Taoyuan station $\left(111^{\circ} 27^{\prime} \mathrm{E}, 28^{\circ} 55^{\prime} \mathrm{N}\right)$ of agro-ecology research, Chinese Academy of Sciences, Hunan Province, China. It has a subtropical monsoon climate with an annual rainfall of $1447 \mathrm{~mm}$ and annual average temperature of $16.5^{\circ} \mathrm{C}$. The soil is classified as hydragric anthrosols (World Reference Base WRB system) with a silt loam texture (clay $8.6 \%$, silt $81.0 \%$ and sand $10.4 \%$ ) derived from quaternary red clay earth. The site was established in 1990 with a random plot designed double-harvest rice system, including triplicate plots of 10 treatments. In this study, bulk soil samples $(0-15 \mathrm{~cm})$ were collected in September 2010 (grain filling stage during rice cultivation) from the following five treatments: control without fertilizers (control); chemical fertilizer nitrogen $(\mathrm{N})$; chemical fertilizers $\mathrm{N}$ and phosphate (NP); $\mathrm{N}$ and potassium $(\mathrm{NK})$; and $\mathrm{N}, \mathrm{P}$ and $\mathrm{K}$ (NPK). The amount of chemical fertilizer was $182.3 \mathrm{~kg} \mathrm{~N}, 39.3 \mathrm{~kg} \mathrm{P}$ and $197.2 \mathrm{~kg} \mathrm{~K} / \mathrm{ha} / \mathrm{a}$ as urea, superphosphate and potassium chloride, respectively. For each plot $\left(33 \mathrm{~m}^{2}\right)$, a composite sample was collected from a mixture of 10 random soil cores (4 cm diameter, $15 \mathrm{~cm}$ depth). Samples were sealed in sterile plastic bags and transported on ice to the laboratory within 12 h. Each soil sample was partitioned into three subsamples: one stored at $-80{ }^{\circ} \mathrm{C}$ for DNA extractions, the second was partially air-dried and passed through a 2$\mathrm{mm}$ sieve for chemical analyses, and the third was stored at $4{ }^{\circ} \mathrm{C}$ for analyses of the biological characteristics within 3 days.

\section{Soil chemical and biological analyses}

Soil chemical parameters were analysed as follows: soil $\mathrm{pH}$ in $\mathrm{KCl}$ was measured at a soil to solution ratio of 1:2.5 (w/v) using a $\mathrm{pH}$ meter (Mettler-Toledo FE 20; Switzerland); total $\mathrm{C}$ and $\mathrm{N}$ were measured by 
combustion at $1200{ }^{\circ} \mathrm{C}$ using an Element Analyzer (Vario EL III; Elementar, USA); nitrate $\left(\mathrm{NO}_{3}^{-}\right)$; ammonium $\left(\mathrm{NH}_{4}^{+}\right)$was extracted with $2 \mathrm{M} \mathrm{KCl}$ at a soil to solution ratio of 1:10 (w/v) for $30 \mathrm{~min}$, and concentrations were determined with an automated Continuous Flow Analyzer (SAN++; SKALAR, The Netherlands); available P was extracted with $0.5 \mathrm{M} \mathrm{NaHCO}_{3}(\mathrm{pH}$ 8.5) at a soil to solution ratio of 1:20 (w/v) for $30 \mathrm{~min}$ and measured by a colorimetric procedure (Bao 1999a); available K was extracted with $1 \mathrm{M} \mathrm{CH}_{3} \mathrm{COONH}_{4}(\mathrm{pH}$ 7.0) at a soil to solution ratio of $1: 10(\mathrm{w} / \mathrm{v})$ for $30 \mathrm{~min}$ and determined by atomic absorption spectrometry (Bao 1999b).

Soil biological parameters were analysed as follows: microbial biomass $\mathrm{C}$ and $\mathrm{N}$ were measured according to Wu et al. (1990) and Jenkinson (1988), respectively; microbial biomass $\mathrm{P}$ was measured according to $\mathrm{Wu}$ et al. (2000); cellulase enzyme activities were measured according to Mersi and Schinner (1995); urease enzyme activities and nitrate reductase enzyme activities were measured according to Kandeler (1995a,b); acid phosphatase, arylsulfatase and dehydrogenase enzyme activities were measured according to Tabatabai (1994); catalase and polyphenol oxidase enzyme activities were measured according to Guan (1986); nitrification potential was measured according to Schmidt and Belser (1994); and denitrification was measured using denitrifier enzyme activity (Tiedje 1994). All tests were performed in triplicate.

\section{Soil DNA extraction}

High molecular weight community DNA was extracted by the freeze-grinding, SDS-based method (Zhou et al. 1996) and was purified using a low-melting agarose gel followed by phenol extraction. DNA concentration and quality were determined using a NanoDrop ND-1000 spectrophotometer (NanoDrop Technologies Inc., Wilmington, DE, USA).

\section{$16 S$ rRNA gene amplification, pyrosequencing and data analysis}

DNA extracted from the soil samples served as template to prepare 16S rRNA gene libraries as previously described (Yang et al. 2014). Acquired pyrosequencing data were processed using RDP's Pyrosequencing Pipeline (http://pyro.cme.msu.edu/) to filter low-quality sequences and trim off the barcodes and primers. Chimeric sequences were detected and removed using UCHIME (Edgar et al. 2011) with the 'gold' reference database from the Broad Institute (available from the USEARCH website at http://drive5.com/uchime/gold. $\mathrm{fa})$. The chimera free sequences were aligned and clustered into OTUs at the $97 \%$ similarity level using RDP pipeline tools. Representative sequences were retrieved and classified using RDP classifier, after which a phylogenetic tree of the representative sequences was created with FASTTREe (Price et al. 2009). Further processing and analysis was performed using $\mathrm{R}$ version 2.15.2 (The $\mathrm{R}$ Foundation for Statistical Computing, Vienna, Austria) with VEGAN (Oksanen et al. 2012), LABDSv (Roberts 2012), BIODIVERSITYR (Kindt \& Coe 2005) and the Bioconductor packages DECIPHER (Wright 2012) and PHYLOSEQ (McMurdie \& Holmes 2013). Representative sequences identified as chimeric by DECIPHER were removed, as were those identified as archaea, unclassified root and chloroplasts. Global singletons were also removed prior to diversity estimation, principal component analysis (PCA) and correlation with environmental parameters. The difference between microbial communities was calculated using the unweighted Unifrac metric after rarefaction to the same sequencing depth and visualized with principal coordinate analysis (PCoA). All sequences were deposited in the National Center for Biotechnology Information Sequence Read Archive under the Accession no. SRP043656.

\section{GEOCHIP 4.0 hybridization and data analysis}

GEOCHIP 4.0 hybridization was performed as described previously ( $\mathrm{Lu}$ et al. 2012; Yang et al. 2013). In brief, extracted DNA was labelled with the fluorescent dye Cy-5 by random priming; hybridization was carried out hybridized on a MAUI Hybridization Station (Roche, South San Francisco, CA, USA) for $16 \mathrm{~h}$ at $42{ }^{\circ} \mathrm{C}$ in the presence of $40 \%$ formamide. The arrays were scanned using a MS 200 Microarray Scanner (Nimblegen, Madison, WI, USA), and the signal intensities were quantified and processed using the data analysis pipeline as previously described (He et al. 2010; Yang et al. 2013).

\section{Statistical analyses}

Statistical analysis was performed as described previously (Lu et al. 2012; Yang et al. 2013). Detrended correspondence analysis, three nonparametric tests (multiple response permutation procedure; permutational multivariate analysis of variance, Adonis; analysis of similarity, anosim), canonical correlation analysis (CCA), variation partitioning analysis (VPA), Mantel test and analysis of variance (ANOVA) were performed using VEGAN package in $\mathrm{R}$ version 3.0.0 (The R Foundation for Statistical Computing). Differences between treatments were compared by post hoc Fisher's least significant difference (LSD) test with Holm-Bonferroni adjustment. The significant differences were defined as $P<0.05$, or with listed $P$-values. 


\section{Results}

\section{Soil chemical and biological parameters}

The chemical and biological properties of soil are listed in Tables 1 and 2, respectively. PCA of chemical data indicated that long-term chemical fertilization changed the chemical ordination patterns of all the treatments, as they were well separated from control samples. About $76.8 \%$ of the total variance was explained by the first two axes, with PC1 and PC2 explaining $41.2 \%$ and $35.6 \%$ of the total variance, respectively. Samples from treatments $\mathrm{N}$ and NK were clustered together and well separated from treatments NP and NPK (Fig. S1, Supporting information).

Soil process measurements showed that long-term chemical fertilization improved soil nutrient contents and microbial activity (Tables 1 and 2). Compared with the control, no obvious change in soil $\mathrm{pH}$ was observed in the N, NP, NK and NPK treatments. The content of soil total $\mathrm{C}$ and $\mathrm{N}$, microbial biomass $\mathrm{C}, \mathrm{N}$ and $\mathrm{P}$, and dehydrogenase activity in all four chemical fertilization treatments $(\mathrm{N}, \mathrm{NP}, \mathrm{NK}$ and NPK) were significantly greater than the control, while there were no significant differences in these parameters between fertilization treatments. Among all the treatments (control, N, NP, NK and NPK), the highest ammonium content was in the $\mathrm{N}$ treatment and the lowest in the NPK treatment; the highest nitrate content was in the NPK treatment and the lowest in the $\mathrm{N}$ treatment. In addition, the $\mathrm{N}$ treatment had the greatest nitrification potential, acid phosphatase activity and arylsulfatase activity, which were $111-233 \%, 20.1-49.4 \%$ and $4.2-15.3 \%$ greater than the other treatments (control, NP, NK and NPK), respectively. Soils in the NP treatment contained much more available $\mathrm{P}$ and supported greater nitrate reductase activity and denitrification potential than soils in the other treatments (control, N, NK and NPK). The largest available $\mathrm{K}$ content was detected in the NK treatment and was about 1.1-2.0 times larger than that in the other treatments (control, N, NP and NPK).

The NPK treatment had the highest cellulase activity, urease activity, catalase activity and polyphenol oxidase activity, which were $33.9-51.4 \%, 7.8-23.8 \%, 3.3-32.9 \%$ and $5.7-14.3 \%$ higher than the other treatments (control, $\mathrm{N}, \mathrm{NP}$ and NK), respectively. According to the average rice yields over 5 years from 2005 to 2009 (Fig. S2, Supporting information), the NPK and NP treatments had the first and second highest rice yields, about 12000 and $10000 \mathrm{~kg} / \mathrm{ha}$, respectively. The lowest rice yields (around $7000 \mathrm{~kg} / \mathrm{ha}$ ) were in all the treatments that did not receive $\mathrm{P}$ fertilizer (control, $\mathrm{N}$ and $\mathrm{NK}$ ).

\section{Phylogenetic diversity of bacterial communities}

A total of 41082 bacterial sequences were obtained for the 15 samples, with sequences per sample ranging from 2304 to 3268 . At the $3 \%$ dissimilarity level, these sequences clustered into 3448 OTUs. Representative sequences of these OTUs were assigned taxonomy with the RDP classifier. There were no obvious differences among treatments at the phylum level (Fig. S3, Supporting information). The most prevalent phyla, in descending order by abundance, were Proteobacteria, Acidobacteria, Chloroflexi, Nitrospira, Firmicutes, Planctomycetes, WS3, Verrucomicrobia, Gemmatimonadetes and Spirochaetes. Unidentified bacteria accounted for $20.4 \%$ of all sequences. The most abundant OTU was classified as Bradyrhizobium (Fig. S4, Supporting information), and $3.1 \%$ of all sequences were classified to this genus.

Chao1 estimator was used to evaluate the phylogenetic diversity of bacterial community, and no significant difference was observed between the control and the long-term chemical fertilized samples $(P>0.05)$ (Fig. S5A, Supporting information). Renyi diversity profiles were plotted to assess differences in species richness and evenness among treatments (Fig. S5B, Supporting information). There were no significant

Table 1 Chemical properties of the soil under different fertilization treatments

\begin{tabular}{llllllll}
\hline Treatment* & $\mathrm{pH}(\mathrm{KCl})$ & $\begin{array}{l}\text { Total C } \\
(\mathrm{g} / \mathrm{kg})\end{array}$ & $\begin{array}{l}\text { Total N } \\
(\mathrm{g} / \mathrm{kg})\end{array}$ & $\begin{array}{l}\text { Nitrate } \\
(\mathrm{mg} / \mathrm{kg})\end{array}$ & $\begin{array}{l}\text { Ammonium } \\
(\mathrm{mg} / \mathrm{kg})\end{array}$ & $\begin{array}{l}\text { Available P } \\
(\mathrm{mg} / \mathrm{kg})\end{array}$ & $\begin{array}{l}\text { Available K } \\
(\mathrm{mg} / \mathrm{kg})\end{array}$ \\
\hline Control & $4.06 \pm 0.03 \mathrm{c}^{\dagger}$ & $19.4 \pm 0.72 \mathrm{~b}$ & $1.85 \pm 0.06 \mathrm{~b}$ & $2.87 \pm 0.18 \mathrm{~d}$ & $24.2 \pm 1.68 \mathrm{~d}$ & $1.22 \pm 0.21 \mathrm{~d}$ & $59.1 \pm 4.13 \mathrm{~d}$ \\
$\mathrm{~N}$ & $4.16 \pm 0.05 \mathrm{~b}$ & $21.5 \pm 1.69 \mathrm{a}$ & $2.27 \pm 0.15 \mathrm{a}$ & $2.75 \pm 0.16 \mathrm{~d}$ & $51.6 \pm 1.45 \mathrm{a}$ & $2.46 \pm 0.43 \mathrm{c}$ & $66.2 \pm 4.11 \mathrm{c}$ \\
$\mathrm{NP}$ & $4.09 \pm 0.08 \mathrm{c}$ & $22.4 \pm 2.49 \mathrm{a}$ & $2.32 \pm 0.15 \mathrm{a}$ & $4.71 \pm 0.03 \mathrm{c}$ & $28.1 \pm 1.13 \mathrm{c}$ & $11.8 \pm 0.77 \mathrm{a}$ & $63.4 \pm 4.00 \mathrm{~cd}$ \\
$\mathrm{NK}$ & $4.23 \pm 0.04 \mathrm{a}$ & $21.1 \pm 1.81 \mathrm{a}$ & $2.20 \pm 0.14 \mathrm{a}$ & $5.29 \pm 0.01 \mathrm{~b}$ & $45.2 \pm 1.23 \mathrm{~b}$ & $2.20 \pm 0.47 \mathrm{c}$ & $175 \pm 12.1 \mathrm{a}$ \\
NPK & $4.05 \pm 0.05 \mathrm{c}$ & $22.4 \pm 1.90 \mathrm{a}$ & $2.32 \pm 0.20 \mathrm{a}$ & $6.45 \pm 0.17 \mathrm{a}$ & $18.3 \pm 0.65 \mathrm{e}$ & $10.7 \pm 0.73 \mathrm{~b}$ & $83.2 \pm 3.91 \mathrm{~b}$ \\
\hline
\end{tabular}

*Treatment: control without fertilizers (control); chemical fertilizer nitrogen $(\mathrm{N})$; chemical fertilizers $\mathrm{N}$ and phosphorus (NP); N and potassium (NK); N, P and K (NPK).

${ }^{\top}$ Mean \pm standard deviation $(n=3)$. Values within the same column followed by the same letter do not differ at $P<0.05$. 
Table 2 Biological properties of the soil under different fertilization treatments

\begin{tabular}{|c|c|c|c|c|c|}
\hline \multirow[b]{2}{*}{ Soil property (per gram soil) } & \multicolumn{5}{|l|}{ Treatment* } \\
\hline & Control & $\mathrm{N}$ & NP & NK & NPK \\
\hline Microbial biomass $C \mu \mathrm{g}$ & $807 \pm 63.4 \mathrm{~b}^{\dagger}$ & $945 \pm 72.1 \mathrm{a}$ & $995 \pm 78.5 \mathrm{a}$ & $919 \pm 73.6$ a & $1026 \pm 81.5 \mathrm{a}$ \\
\hline Microbial biomass $\mathrm{N} \mu \mathrm{g}$ & $62.7 \pm 4.28 \mathrm{~b}$ & $85.6 \pm 6.66 \mathrm{a}$ & $86.5 \pm 6.68 \mathrm{a}$ & $82.5 \pm 5.60 \mathrm{a}$ & $87.7 \pm 6.19 \mathrm{a}$ \\
\hline Microbial biomass $\mathrm{P} \mu \mathrm{g}$ & $21.3 \pm 1.03 \mathrm{~b}$ & $27.6 \pm 1.52 \mathrm{a}$ & $29.1 \pm 1.83 \mathrm{a}$ & $27.3 \pm 1.47 \mathrm{a}$ & $30.4 \pm 1.70 \mathrm{a}$ \\
\hline Cellulase $\mu$ g glucose per day & $146 \pm 6.88 \mathrm{~d}$ & $161 \pm 9.24 \mathrm{~cd}$ & $165 \pm 8.88 \mathrm{bc}$ & $155 \pm 6.98 \mathrm{~d}$ & $221 \pm 9.38 \mathrm{a}$ \\
\hline Urease $\mu \mathrm{g} \mathrm{NH} \mathrm{N}_{4}^{+}-\mathrm{N}$ per hour & $30.3 \pm 1.40 \mathrm{c}$ & $34.8 \pm 1.67 \mathrm{ab}$ & $34.1 \pm 1.17 \mathrm{~b}$ & $31.7 \pm 1.54 \mathrm{c}$ & $37.5 \pm 1.17 \mathrm{a}$ \\
\hline Nitrate reductase $\mu \mathrm{g} \mathrm{NO}_{2}^{-}-\mathrm{N}$ per day & $0.50 \pm 0.05 \mathrm{e}$ & $0.88 \pm 0.06 \mathrm{~b}$ & $1.27 \pm 0.06 \mathrm{a}$ & $0.82 \pm 0.05 \mathrm{c}$ & $0.60 \pm 0.05 \mathrm{~d}$ \\
\hline Acid phosphatase $\mu \mathrm{g}$ p-nitrophenol per hour & $1410 \pm 37.3 c$ & $2107 \pm 56.4 \mathrm{a}$ & $1755 \pm 51.1 \mathrm{~b}$ & $1699 \pm 41.4 \mathrm{~b}$ & $1722 \pm 39.8 \mathrm{~b}$ \\
\hline Arylsulfatase $\mu \mathrm{g}$ p-nitrophenol per hour & $1025 \pm 21.0 \mathrm{c}$ & $1182 \pm 36.3 \mathrm{a}$ & $1134 \pm 41.3 \mathrm{~b}$ & $1133 \pm 37.7 b$ & $1116 \pm 25.1 \mathrm{~b}$ \\
\hline Catalase $\mathrm{mL} 0.1 \mathrm{~N} \mathrm{~K} \mathrm{MnO}_{4} /(20 \mathrm{~min})$ & $1.43 \pm 0.03 \mathrm{e}$ & $1.60 \pm 0.03 c$ & $1.84 \pm 0.03 \mathrm{~b}$ & $1.54 \pm 0.04 \mathrm{~d}$ & $1.90 \pm 0.06 \mathrm{a}$ \\
\hline Dehydrogenase $\mu \mathrm{g}$ triphenyl formazan per day & $20.4 \pm 1.25 \mathrm{~b}$ & $24.2 \pm 1.06 \mathrm{a}$ & $24.7 \pm 1.09 \mathrm{a}$ & $23.3 \pm 1.14 \mathrm{a}$ & $23.1 \pm 1.22 \mathrm{a}$ \\
\hline Polyphenol oxidase $\mu \mathrm{g}$ gallicin per hour & $210 \pm 9.88 c$ & $219 \pm 8.97 \mathrm{bc}$ & $227 \pm 7.62 \mathrm{ab}$ & $225 \pm 2.75 \mathrm{~b}$ & $240 \pm 10.9 a$ \\
\hline Nitrification $\mu \mathrm{g} \mathrm{NO}_{3}^{-}$per day & $0.12 \pm 0.01 \mathrm{~d}$ & $0.40 \pm 0.02 \mathrm{a}$ & $0.16 \pm 0.01 \mathrm{c}$ & $0.19 \pm 0.01 \mathrm{~b}$ & $0.15 \pm 0.01 \mathrm{c}$ \\
\hline Denitrification $\mu \mathrm{g} \mathrm{N}_{2} \mathrm{O}-\mathrm{N}$ per hour & $0.49 \pm 0.04 \mathrm{~d}$ & $0.84 \pm 0.07 \mathrm{~b}$ & $1.06 \pm 0.06 \mathrm{a}$ & $0.90 \pm 0.07 \mathrm{~b}$ & $0.62 \pm 0.05 c$ \\
\hline
\end{tabular}

*Treatment: control without fertilizers (control); chemical fertilizer nitrogen (N); chemical fertilizers N and phosphorus (NP); $\mathrm{N}$ and potassium (NK); N, P and K (NPK).

Mean \pm standard deviation $(n=3)$. Values within the same row followed by the same letter do not differ at $P<0.05$.

differences in species richness, but evenness was greater for the control samples which differed significantly $(P \leq 0.05)$ from treatments receiving P. PCoA of unweighted unifrac-based beta diversity showed that replicate samples from each treatment could not be clustered together (Fig. S6A, Supporting information). Minor differences in community structure due to addition of $\mathrm{P}$ were also evident by PCA, but at first glance, this is not obvious. The first two PCs explain relatively little variance $(22 \%)$, replicate samples did not cluster well by treatment (Fig. S6B, Supporting information), there were no significant $(P \leq 0.05)$ differences in community structure between treatments detected by permutational multivariate analysis (Table 3), and nor were significant indicator species (adjusted $P \leq 0.05$ ) for any treatment detected by indval ( $\mathrm{R}$ package LABDSV) or function $\mathrm{mt}$ (Bioconductor package PHYLOSEQ). However, the second PC represented a gradient in available phosphorous and separated samples according to whether or not $\mathrm{P}$ was added (Fig. S6B, Supporting information). Taken together with the differences in evenness among treatments, these results suggest that the proportions of certain OTUs increased in response to higher available $\mathrm{P}$.

Direct gradient analysis was used to determine which OTUs were correlated with available $\mathrm{P}$. This was carried out for both OTUs containing at least 25 sequences and for OTUs agglomerated by genus. Examples of OTUs and genera with more sequences in treatments receiving $\mathrm{P}$ are depicted in Fig. S7 (Supporting information). The abundances of Bradyrhizobium, Gemmatimonas, Smithella and Syntrophobacteriaceaea were all positively correlated with available $\mathrm{P}$, as were many other OTUs.
Table 3 Adonis tests of the effects of chemical fertilization on the overall microbial community structure based on GEOCHIP 4.0 data and $16 \mathrm{~S}$ rDNA sequencing data

\begin{tabular}{lllllll}
\hline & \multicolumn{3}{l}{ GEOCHIP } & & & \multicolumn{2}{l}{ 16S rDNA } \\
\cline { 2 - 3 } \cline { 6 - 7 } \cline { 5 - 6 } & $F$ & $P$-value & & $F$ & $P$-value \\
\hline Control vs N & 0.667 & 0.027 & & 0.2137 & 0.38 \\
Control vs NP & 0.46 & 0.019 & & 0.26326 & 0.09 \\
Control vs NK & 0.834 & 0.032 & & 0.20999 & 0.37 \\
Control vs NPK & 0.833 & 0.001 & & 0.26265 & 0.06 \\
\hline
\end{tabular}

$\mathrm{NP}, \mathrm{N}$ and phosphate; NK, N and potassium; NPK, N, P and $\mathrm{K}$.

Adonis: Permutational multivariate analysis of variance using distance matrices. Significance tests were performed by F-tests based on sequential sums of squares from permutations of the raw data.

\section{Long-term fertilization changed the microbial functional gene diversity and structure}

Different functional gene structure detected by GEOCHIP showed that samples from each treatment were clustered together and separated by the first axis from the control samples and that samples from treatments NK and NPK were separated by the second axis (Fig. 1). Significant difference $(P<0.05)$ was observed between the control and the samples with chemical fertilization when a nonparametric multivariate statistical test, adonis, was analysed based on the GEOCHIP 4.0 data (Table 3). Chemical fertilization significantly increased the diversity of functional genes involved in $\mathrm{C}, \mathrm{N}, \mathrm{P}, \mathrm{S}$ cycling, especially for the treatments NK and NPK (Fig. 


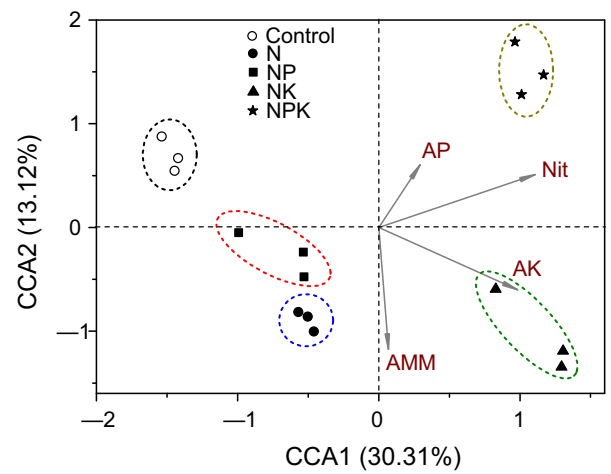

Fig. 1 Canonical correspondence analysis (CCA) compares the GEOCHIP hybridization signal intensities (symbols) and environmental variables (arrows), including nitrate (Nit), ammonium (AMM), available potassium (AK) and available phosphorous (AP). Environmental variables were chosen based on significance calculated from individual CCA results and variance inflation factors (VIFs) calculated during CCA. The percentage of variation explained by each axis is shown, and the relationship is significant $(P=0.005)$.

S8, Supporting information). Thus, these results indicate that, although the phylogenetic compositions of microbial communities as assessed by 16S rRNA data were similar, the soil microbial community functional gene structure was significantly affected by long-term chemical fertilization.

The relationships between microbial community functional structure and soil chemical parameters were assessed with canonical correspondence analysis (CCA) (Fig. 1). Four parameters, nitrate (Nit), ammonium (AMM), available potassium (AK) and available phosphorous (AP) were selected based on variance inflation factors and significant test. Over $60 \%$ of the community functional variation can be explained by the aboveselected variables based on GEOCHIP data. The result showed that the control and chemically fertilized samples were grouped separately. The first canonical axis was positively correlated with the concentrations of nitrate and available potassium, and the second axis was positively correlated with concentration of $\mathrm{AP}$ and negatively correlated with ammonium. Nit, AMM and AK appeared to play major roles in shaping microbial community functional structure as important variables are represented by longer arrows. Treatment NK was positively correlated with AK. Treatment NPK was positively affected by AP and Nit, while N and NP were negatively correlated with $\mathrm{AP}$ and Nit and were positively affected by AMM. CCA-based VPA was performed to separate the effects of nitrogen, phosphorous and potassium fertilizers on microbial community structure (Fig. 2). Nitrate and ammonium explained substantially more variation $(25.4 \%$, ) than available phosphorous (9.3\%) and available potassium (9.2\%).

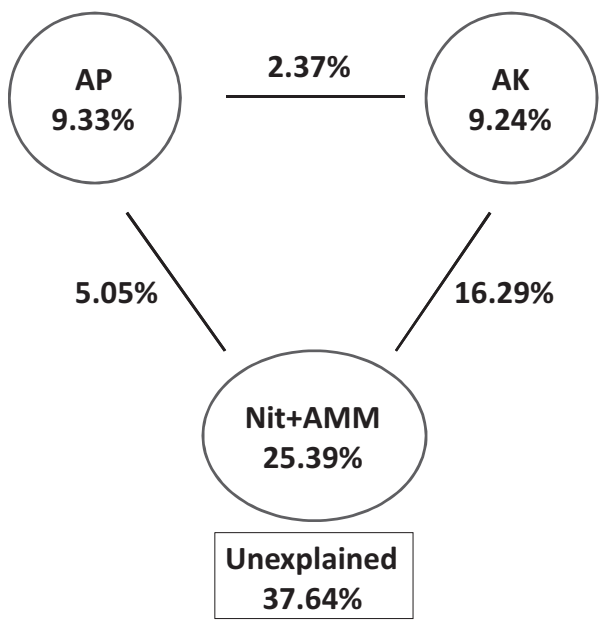

Fig. 2 Variation partitioning analysis of microbial functional diversity explained by soil chemical parameters based on GEOCHIP 4.0 data. Environmental variables include nitrate (Nit), ammonium (AMM), available potassium (AK) and available phosphorous (AP).

Interaction between nitrogen and $\mathrm{AK}$ accounted for $16.3 \%$ of the variation, which is much stronger than the interactions between nitrogen and $\mathrm{AP}(5.1 \%)$, or $\mathrm{AP}$ and AK (2.4\%). There was zero variance attributed to the interaction of all variables.

\section{Effect of chemical fertilization on microbial functional genes}

Carbon cycling. As a major biogeochemical process in paddy soils, microbial functional genes responsible for degradation of starch, hemicellulose, cellulose, pectin, chitin and lignin were detected in all samples. $\mathrm{N}$ fertilizer significantly enhanced the normalized signal intensity of most genes involved in cellulose, pectin and chitin degradation. $\mathrm{N}$ and $\mathrm{K}$ fertilizer enhanced most of the genes involved in starch, cellulose, pectin and chitin degradation except neopullulanase for starch degradation and arabinofuranosidase for hemicellulose degradation. N, K and P fertilizer showed a pattern similar to that of $\mathrm{N}$ and $\mathrm{K}$ fertilizer. $\mathrm{N}$ and $\mathrm{P}$ fertilizer enhanced glucoamylase and pullulanase for starch degradation, xylanase for hemicellulose degradation, and cellobiase and exoglucanase for cellulose degradation. The abundances of genes involved in lignin degradation were largely unchanged by chemical fertilization. The fact that most of the genes that were significantly affected by chemical fertilization increased in abundance (Fig. 3) suggests that long-term chemical fertilization may stimulate carbon degradation processes in paddy soils.

Nitrogen cycling. The application of $\mathrm{N}$ fertilizer significantly enhanced most genes (norB, nosZ and nirS) 

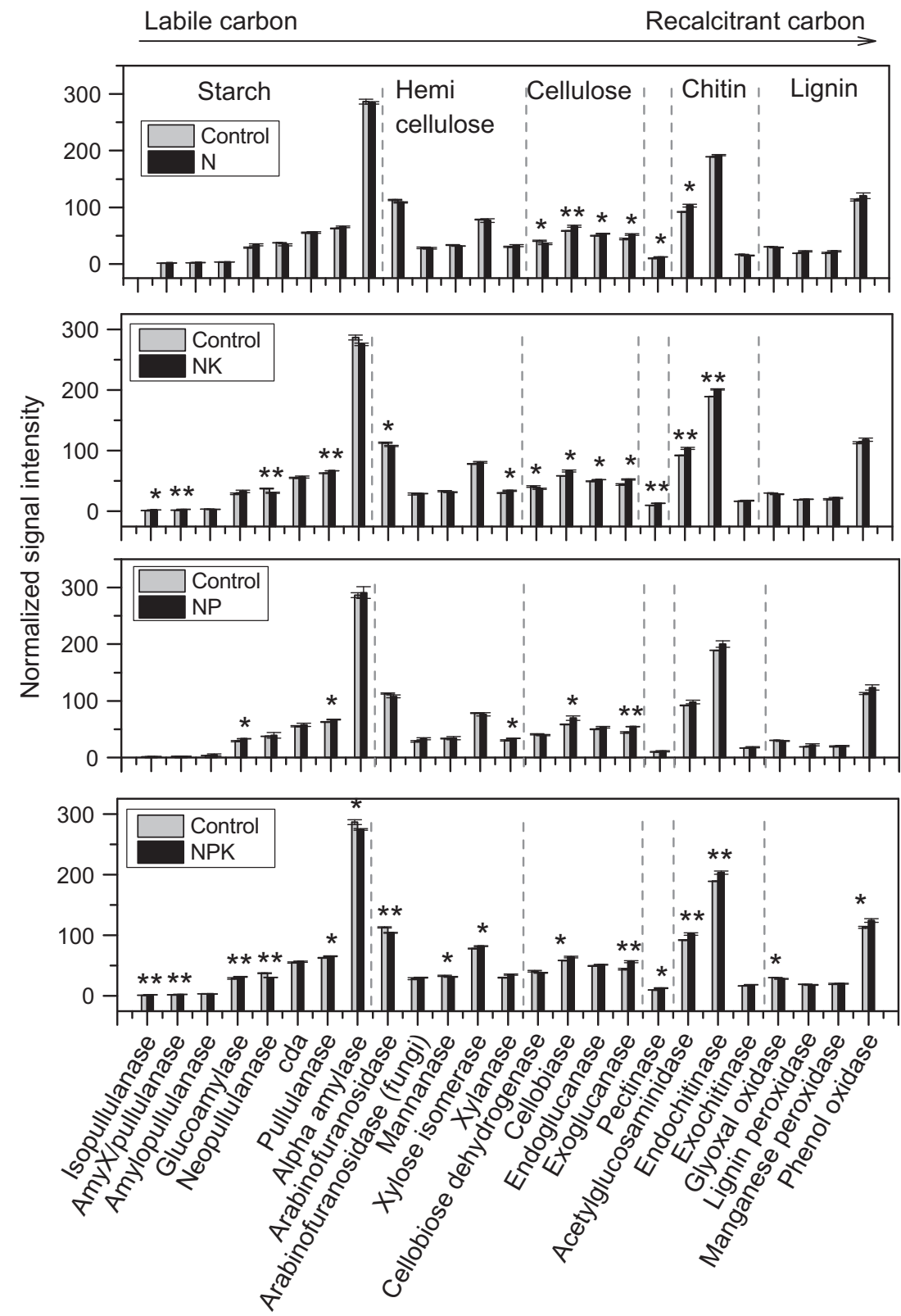

Fig. 3 The normalized average signal intensity of the detected functional genes involved in carbon degradation. All data are presented as the mean $\pm \mathrm{SE}$. $* * P<0.01, * P<0.05$. involved in denitrification, nas $A$ for assimilatory $\mathrm{N}$ reduction and the archaea-derived amo $A$ gene for nitrification (Fig. 4). Further, nirS/K, norB and nosZ for denitrification, napA and $n r f A$ for dissimilatory $\mathrm{N}$ reduction, nas $A$ for assimilatory $\mathrm{N}$ reduction, $g d h$ for ammonification and archaea-derived amo $A$ gene for nitrification exhibited significantly higher signal intensities in N, K and P fertilized samples (Figs 4 and S9, Supporting information). Similar pattern was observed for the treatment with $\mathrm{N}$ and $\mathrm{K}$ fertilizer, while $\mathrm{N}$ and $P$ fertilizer only enhanced nirS for denitrification and napA for dissimilatory $\mathrm{N}$ reduction (Fig. 4). The normalized signal intensity of amo $A$ from archaea was significantly increased by NK and NPK, while amoA from bacteria decreased after chemical fertilization. However, diversity of amo $A$ from both archaea and bacteria was increased by chemical fertilization (Fig. 5). The fact that most of the genes involved in nitrogen cycling were detected with significantly higher signal intensity in chemical fertilized samples (Figs S9 and S10, Supporting information) implies that chemical fertilizer may accelerate the geochemical cycle of nitrogen in paddy soils.

$P$ cycling. The GEOCHIP 4.0 targets three enzymes involved in $\mathrm{P}$ utilization. Genes encoding phytase for phytate degradation showed no difference between control and long-term chemical fertilized soils and long- 

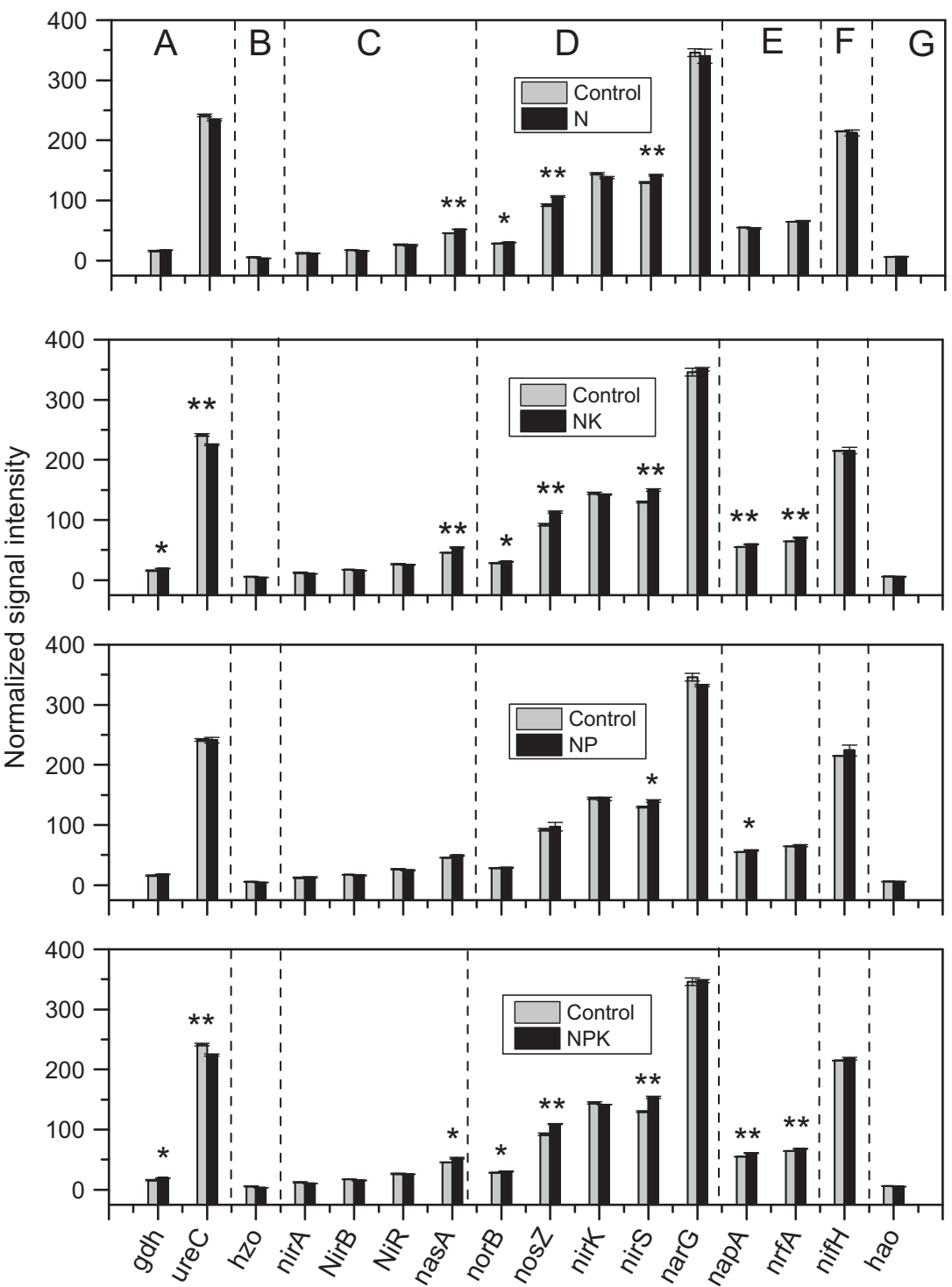

Fig. 4 The normalized average signal intensity of the detected key functional genes involved in $\mathrm{N}$ cycling. (A) Ammonification, including $g d h$ for glutamate dehydrogenase and ureC encoding urease; (B) Annamox, including hzo encoding hydrazine oxidoreductase; (C). Assimilatory $\mathrm{N}$ reduction, including nir $A /$ nirB/NiR encoding nitrite reductase, nas $A$ encoding nitrate reductase; (D) Denitrification, including narG for nitrate reductase, nirS and nirK for nitrite reductase, nor $B$ for nitric oxide reductase and nosZ for nitrous oxide reductase; (E) Dissimilatory $\mathrm{N}$ reduction to ammonium, including nap $A$ for nitrate reductase and nrfA for c-type cytochrome nitrite reductase; (F) $\mathrm{N}_{2}$ fixation, including nifH encoding nitrogenase; (G) Nitrification, including hao for hydroxylamine oxidoreductase. All data are presented as the mean \pm SE. $* * P<0.01, * P<0.05$. term cultivation samples. Genes encoding polyphosphate kinase $(p p k)$ for polyphosphate biosynthesis in prokaryotes was detected with significantly $(P<0.01)$ increased abundances after long-term chemical fertilization, while genes encoding exopolyphosphatase ( $p p x)$ for inorganic polyphosphate degradation were significantly $(P<0.01)$ decreased (Fig. S11, Supporting information).

Methane. Three genes encoding enzymes involved in methane metabolism were included in GEOCHIP 4.0: $\mathrm{mcr} A$ encoding the alpha-subunit of methyl coenzyme $\mathrm{M}$ reductase for methane production, pmoA encoding particulate methane monoxygenase and mmoX encoding methane monoxygenase for methane oxidation. For all the three genes, significantly $(P<0.01)$ higher signal intensities were detected in chemically fertilized soils, particularly for $m c r A$ and $p m o A$, suggesting that stronger methane metabolism could occur after long-term chemical fertilization, which might accelerate the methane cycling processes (Fig. S12, Supporting information).

\section{Relationship between microbial community functional genes and soil properties}

Mantel tests were performed to investigate the relationship between microbial community functional structure and soil properties (Table 4), which showed that the chemical variables were highly correlated with changes in microbial functional communities, especially nitrate, total nitrogen and available potassium. Denitrification activity in soil was significantly correlated with the genes involved in denitrification and to nar $\mathrm{G}$, nirK, nirS 

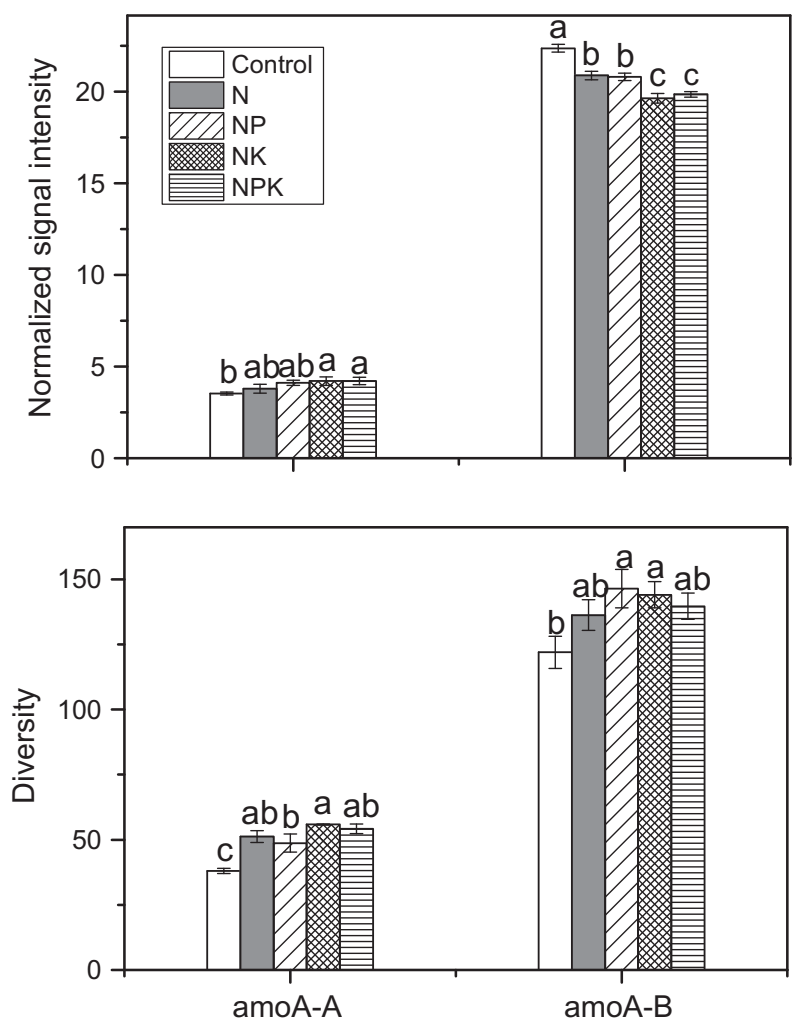

Fig. 5 The normalized average signal intensity and diversity of the detected amoA genes. Diversity was represented with inverse Simpson indice. amo $A-A$, archaeal amo $A$ genes; $a m o A-B$, bacterial amo $A$ genes. All data were presented as the mean \pm SE. Bars with the same letter do not differ at $P<0.05$.

and nosZ, respectively. Nitrate reductase activity was significantly correlated with the genes involved in denitrification and with the nitrate reductase encoding genes narG and napA. Significant correlations were detected between all the genes involved in nitrogen cycling and soil biomass N. Acid phosphomonoesterase was significantly correlated with the genes involved in phosphorous cycling and further with phytase gene and exopolyphosphatase encoding $p p x$ gene. These results suggested that microbial community functional gene structure could significantly affect the soil process and nutrient (Table 2).

\section{Discussion}

Due to heavy weathering and nutrient leaching, the fertility of the paddy soil derived from quaternary red clay is often very low, and rational fertilization is the most important measure to improve yield towards a sustainable crop production (Ahamadou et al. 2009). Previous studies have revealed that $\mathrm{P}$ deficiency is a critical constraint to crop growth in red soil (Ultisols and Oxisols, WRB system), although soil $\mathrm{N}$ is also seriously deficient in red soils, stimulation of crop yields by $\mathrm{N}$ application could be achieved only after improving P supply (Fairhurst et al. 1999; Zhong \& Cai 2007). In this study, applications of $\mathrm{N}$ plus $\mathrm{P}$, and $\mathrm{N}, \mathrm{P}$ plus $\mathrm{K}$ significantly increased rice yield (average value from the year of 2005 to 2009), while applications of $\mathrm{N}$ alone and $\mathrm{N}$ plus $\mathrm{K}$ had no significant effect on rice yield, indicating the importance of long-term $\mathrm{P}$ fertilizer application in promoting crop yield. Furthermore, balanced fertilization of $\mathrm{N}, \mathrm{P}$ plus $\mathrm{K}$ had a higher rice yield than the other fertilization treatments (N, NP and NK), suggesting a positive impact of balanced chemical fertilizer applications on crop production, in accordance with previous reports that balanced fertilization resulted in higher crop yield (Gu et al. 2009; Shang et al. 2014). The PCA of basic chemical properties showed that the NP and NPK treatments were clustered together and distinct from the control, N and NK treatments on PC1, this further confirmed that $\mathrm{P}$ availability is a key factor for nutrient cycling and fertility in this soil.

The influence of long-term fertilization on soil fertilities can be reflected by the changes in soil biological properties. In our study, treatments with chemical fertilization (N, NK, NP and NPK) increased soil microbial biomass $\mathrm{C}, \mathrm{N}$ and $\mathrm{P}$ contents as compared to the control. A recent meta-analysis based on 107 data sets from 64 long-term trials from around the world revealed the increase in soil microbial biomass by mineral fertilizer application (Geisseler \& Scow 2014). In addition, chemical fertilization significantly enhanced the activities of soil oxidoreductase (catalase and dehydrogenase), and most extracellular enzymes involved in C (cellulase and polyphenol oxidase), $\mathrm{N}$ (urease and nitrate reductase), $\mathrm{P}$ (acid phosphatase) and S cycling (arylsulfatase) and were in general agreement with the functional gene data as revealed by GEOCHIP (Tables 2 and 4). This may be the consequence of stimulation of both microbial growth and activity by improved nutrient availability as well as the changes in microbial community composition induced by different fertilization regimes (Chu et al. 2007; Ge et al. 2009; Ai et al. 2012). In addition, the improvement of soil physical properties by chemical fertilization could make the soil environment more favourable for microbial growth (Haynes \& Naidu 1998; Iovieno et al. 2009).

In addition to soil microbial biomass and enzymatic activities, microbial community composition can also be affected by chemical fertilization. Differences of microbial composition in soil with chemical and organic fertilization were identified using PLFA analysis (Zhang et al. 2012). Using this method, Ng et al. (2014a,b) demonstrated that soil carbon is a key factor in driving microbial composition and functioning, and stoichiometric invariance of microbial activity constrained 
Table 4 Correlation between microbial community functional genes and respective soil properties using mantel test

\begin{tabular}{llll}
\hline Gene & Soil property & Statistic $r$ & $P$ \\
\hline All functional genes & All chemical variables & 0.478 & $\mathbf{0 . 0 0 1}$ \\
& Nit & 0.462 & $\mathbf{0 . 0 0 3}$ \\
& AMM & 0.109 & 0.13 \\
AP & 0.122 & 0.115 \\
pH & 0.159 & 0.105 \\
TC & 0.106 & 0.137 \\
TN & 0.294 & $\mathbf{0 . 0 1 9}$ \\
AK & 0.249 & $\mathbf{0 . 0 4 8}$
\end{tabular}

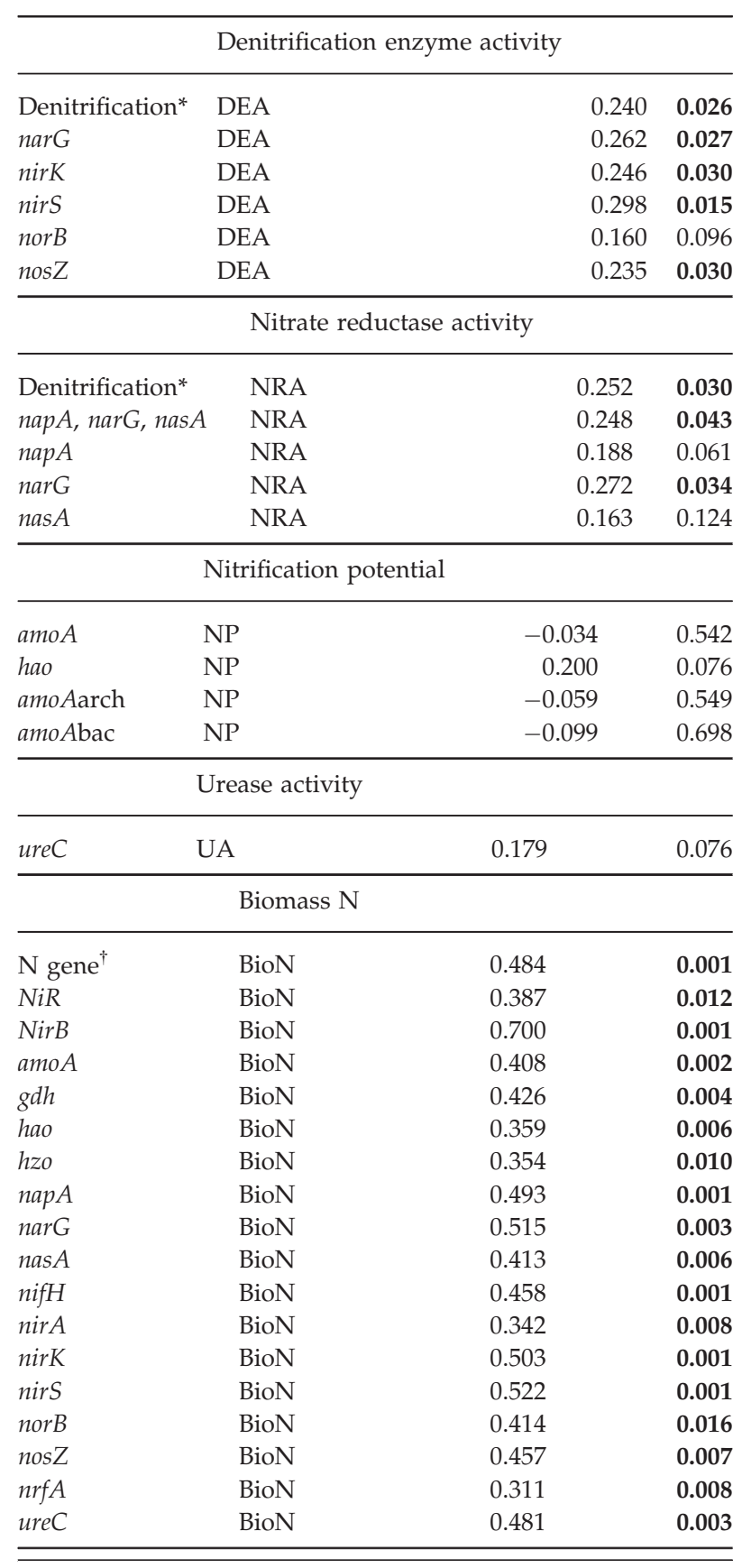

Table 4 Continued

\begin{tabular}{llll}
\hline \multicolumn{5}{c}{ Acid phosphomonoesterase activity } \\
\hline P gene $^{\ddagger}$ & APA & 0.285 & $\mathbf{0 . 0 1 9}$ \\
phytase & APA & 0.380 & $\mathbf{0 . 0 0 3}$ \\
$p p k$ & APA & 0.209 & 0.073 \\
$p p x$ & APA & 0.309 & $\mathbf{0 . 0 1 4}$ \\
\hline
\end{tabular}

$\mathrm{AK}$, available potassium; AMM, ammonium; $\mathrm{AP}$, available phosphorous.

Bold text indicate significant $P$-values $(<0.05)$.

*The signal intensity of all functional genes involved in denitrification.

'The signal intensity of all functional genes involved in nitrogen cycling.

The signal intensity of all functional genes involved in phosphorous cycling.

microbial community response to organic input. Several studies have shown that long-term fertilization regimes resulted in changes in soil bacterial community structure and diversity based on the analysis of 16S rRNA gene libraries. Higher richness and diversity of bacterial communities were found in soil amended with farmyard manure or inorganic $\mathrm{P}$ and $\mathrm{K}$ fertilizers (Ge et al. 2008; Gu et al. 2009). In contrast, other studies showed that overall bacterial community composition was relatively nonresponsive to long-term fertilization (Ogilvie et al. 2008; Wu et al. 2011). This discrepancy between studies may be due at least in part to the limited capacity of their methods in assessing the whole microbial community.

In our study, 16S rRNA gene-based 454-pyrosequencing was employed, providing a more comprehensive assessment of the impact of chemical fertilization on soil microbial composition and diversity than conventional 16S rRNA gene library analysis. Still, statistically significant community differences were not detectable by ordination nor by diversity estimates relying primarily on species richness, which is most likely due to the artefacts associated with random sampling processes (Zhou et al. 2011, 2013). Evenness was, however, lower for samples from fertilized plots, especially those receiving $\mathrm{P}$, suggesting the enrichment of some OTUs. Also, the second PC, while explaining only $10 \%$ of the total variance, did order samples by treatment. When environmental data were fit to the PCA, PC2 was correlated with available $\mathrm{P}$, and this motivated us to re-examine the data using a direct gradient approach. Effects due to $\mathrm{P}$ are especially relevant as it also increased rice yield. By filtering and sorting OTUs based on their correlations with available $\mathrm{P}$ and sequence abundance, we identified those differing in abundance between treatments even though they contributed relatively little to 
the calculated differences between samples on which ordination is based.

While statistical tests were used to sort out OTUs and genera responsive to $\mathrm{P}$ addition, this procedure is best thought of as a data mining technique, and true significance depends on being able to attach biological meaning to the results. Two genera more responsive to $\mathrm{P}$ fertilizer addition were Bradyrhizobium and Gemmatimonas (Fig. S7, Supporting information). Bradyrhizobium is capable of improving nutrient uptake, thus enhancing plant growth and yield (Biswas et al. 2000; Chaintreuil et al. 2000; Egamberdiyeva et al. 2004), which may contribute to the higher rice yield in the $\mathrm{P}$ fertilization treatment (Fig. S2, Supporting information). Gemmatimonas was reported as a polyphosphate-accumulating bacterium (Zhang et al. 2003), which could be stimulated by increased $\mathrm{P}$ input in $\mathrm{P}$ fertilization treatment.

Although the 16S rRNA data revealed only small differences in bacterial community structure, our functional gene array data suggest that soil microbial functional gene structure was greatly affected by longterm chemical fertilization. All the fertilization treatments increased most of the genes involved in carbon degradation and $\mathrm{N}$ cycling (Figs 3 and 4), suggesting that long-term fertilization can accelerate soil $\mathrm{C}$ and $\mathrm{N}$ turnover in the paddy soil. The genes responsible for lignin (relatively more recalcitrant C) degradation remained largely unchanged by chemical fertilization, which may be important in maintaining $C$ stability in soil (He et al. 2010; Zhou et al. 2012). Some previous studies reported that the microbial functional communities were affected by long-term fertilization practices. For example, it was shown that the combined inorganic and organic fertilizer treatments (NPK plus organic manure) had the highest copy numbers of ammoniaoxidizing bacteria and archaea (He et al. 2007). A significant variation in the community diversity of denitrifiers was induced by long-term chemical fertilization (Chen et al. 2010). However, in these studies, only a few functional genes were assessed using quantitative PCR, therefore did not provide an overall picture of the changes in soil microbial functional genes. In this study, for the first time, GEOCHIP was employed to assess microbial functional genes in paddy soils with long-term chemical fertilization, providing comprehensive information regarding the impact of chemical fertilization on the soil microbiome.

It is expected that fertilizer input may stimulate soil nutrient cycling through its modification on the abundance and activity of the related functional microorganisms (Fierer et al. 2012). In this study, significant correlations between denitrification enzymes, nitrate reductase, and phosphomonoesterase and the related functional genes were detected (Table 4), which sup- ported this hypothesis. Previous studies in this field also demonstrated that N and NPK treatment markedly increased the abundance of the denitrifying genes and potential denitrification activity was significantly correlated with narG and nosZ (Chen et al. 2012). However, no significant relationship between ammonia oxidizer (AOA and $\mathrm{AOB}$ ) and nitrification potential was observed, which may due to the changes in mineral $\mathrm{N}$ when using partial air-dried soil for measurement. In addition, the lack of correlation between ammonia oxidizers and nitrification potential may suggest that heterotrophic nitrification process could also be important in acidic soils (De Boer \& Kowalchuk 2001; Zhang et al. 2011). Significant correlations between functional gene data and soil enzyme activities (Table 4) indicate a close linkage between soil nutrient cycling and associated genes (Marschner et al. 2003; Majumder et al. 2007; Nemergut et al. 2008; Wang et al. 2008; Bannert et al. 2011). In addition, significant correlation between rice yield and several soil parameters was observed, including nitrate, available phosphorus, total carbon, total nitrogen, catalase, urease, cellulase, biomass $\mathrm{C}$ and biomass P (Table S1, Supporting information), suggesting a significant relationship between microbial functional gene structure and rice yield.

The application of $\mathrm{N}$ fertilizer can alter soil $\mathrm{N}$ availability and the $\mathrm{N}$-cycling-related microorganisms ( $\mathrm{He}$ et al. 2007). As the stoichiometric patterns of substrate availability determine soil nutrient cycling processes and microbial community composition (Manzoni et al. 2008), N availability can also regulate microbial decomposition of soil organic matter (Yao et al. 2009). Significant differences in microbial functional structure were observed between the control and $\mathrm{N}$ treatment; however, the difference in microbial functional gene structure between the control and the NP treatment is less pronounced as compared to that between the control and the $\mathrm{N}$ treatment (Fig. 1). This is likely due to the interactions between soil nutrients, plant growth and microbial community. It has been well documented that rice production is limited by soil phosphorus $(\mathrm{P})$ deficiencies in many parts of the world (Lan et al. 2012). Due to the $\mathrm{P}$ deficiency in this soil, the application of $\mathrm{P}$ fertilizer greatly increased plant growth (Fig. S2, Supporting information) and further $\mathrm{N}$ uptake, thus resulting in reduced ammonium content in soil as compared with the $\mathrm{N}$ treatment (Table 1). Consequently, the effect of $\mathrm{N}$ fertilizer on soil microbial community composition was weakened by the $\mathrm{P}$ fertilizer application. Further analysis showed that most genes involved in $\mathrm{N}$ cycling were enhanced by $\mathrm{N}$ fertilizer application, while the combination of $\mathrm{N}$ and $\mathrm{P}$ fertilization (NP treatment) only enhanced two groups of $\mathrm{N}$-cycle-related genes (Figs 4 and S10, Supporting information). The NK and 
NPK treatments were very different from other treatments in microbial functional structure, indicating that soil $\mathrm{K}$ availability is also an important factor in driving soil microbial community structure and diversity. Generally, soil $\mathrm{K}$ fertilizer can improve plant root growth, resulting in increased amounts of plant root exudates, which will have direct influence on the composition and activity of microbial communities (Simek et al. 1993). The significant difference in microbial functional structure between NK and NPK treatments indicated an incorporative effect of balanced fertilizer. Most of the genes were stimulated in NPK treatment, which has the highest rice yield, demonstrating the importance of balanced fertilization in promoting soil nutrient, stimulating microbial activity and increasing rice yield.

\section{Conclusions}

In conclusion, our results indicated that long-term chemical fertilization showed little effect on the bacterial phylogenetic diversity and composition; however, it significantly changed the microbial functional gene structure. Most of the functional genes involved in $\mathrm{C}$, $\mathrm{N}, \mathrm{P}$ cycling were significantly stimulated after longterm fertilization. Significant correlations were observed between functional gene abundance and available nutrients and enzyme activities, implicated that long-term chemical fertilization could accelerate the nutrient turnover in paddy soil. Balanced application of $\mathrm{N}, \mathrm{P}$ and $\mathrm{K}$ was more beneficial in improving soil microbial functional diversity and activities compared with other imbalanced fertilization treatments and may contribute to higher rice yield.

\section{Acknowledgements}

This work was supported by the National Natural Science Foundation of China $(41090282,31270153)$ and the Strategic Priority Research Program of Chinese Academy of Sciences, Grant No. XDB15020302.

\section{Conflict of interest}

The authors declare that they have no conflict of interests.

\section{References}

Ahamadou B, Huang Q, Chen W et al. (2009) Microcalorimetric assessment of microbial activity in long-term fertilization experimental soils of Southern China. FEMS Microbiology Ecology, 70, 30-39.

Ai C, Liang G, Sun J, Wang X, Zhou W (2012) Responses of extracellular enzyme activities and microbial community in both the rhizosphere and bulk soil to long-term fertilization practices in a fluvo-aquic soil. Geoderma, 173-174, 330-338.

Bannert A, Kleineidam K, Wissing L et al. (2011) Changes in diversity and functional gene abundances of microbial communities involved in nitrogen fixation, nitrification, and denitrification in a tidal wetland versus paddy soils cultivated for different time periods. Applied and Environmental Microbiology, 77, 6109-6116.

Bao SD (1999a) Analytical Methods of Soil Agrochemistry (in Chinese), pp. 106-109. China Agricultural Press, Beijing.

Bao SD (1999b) Analytical Methods of Soil Agrochemistry (in Chinese), pp. 420-427. China Agricultural Press, Beijing.

Biswas JC, Ladha JK, Dazzo FB (2000) Rhizobia inoculation improves nutrient uptake and growth of lowland rice. Soil Science Society of America Journal, 64, 1644-1650.

Campbell BJ, Polson SW, Hanson TE, Mack MC, Schuur EAG (2010) The effect of nutrient deposition on bacterial communities in Arctic tundra soil. Environmental Microbiology, 12, 1842-1854.

Chaintreuil C, Giraud E, Prin Y et al. (2000) Photosynthetic bradyrhizobia are natural endophytes of the African wild rice Oryza breviligulata. Applied and Environmental Microbiology, 66, 5437-5447.

Chen Z, Luo XQ, Hu RG et al. (2010) Impact of long-term fertilization on the composition of denitrifier communities based on nitrite reductase analyses in a paddy soil. Microbial Ecology, 60, 850-861.

Chen Z, Liu J, Wu M et al. (2012) Differentiated response of denitrifying communities to fertilization regime in paddy soil. Microbial Ecology, 63, 446-459.

Chu HY, Lin XG, Fujii T et al. (2007) Soil microbial biomass, dehydrogenase activity, bacterial community structure in response to long-term fertilizer management. Soil Biology $\mathcal{E}$ Biochemistry, 39, 2971-2976.

De Boer W, Kowalchuk GA (2001) Nitrification in acid soils: micro-organisms and mechanisms. Soil Biology and Biochemistry, 33, 853-866.

Edgar RC, Haas BJ, Clemente JC, Quince C, Knight R (2011) UCHIME improves sensitivity and speed of chimera detection. Bioinformatics, 27, 2194-2200.

Egamberdiyeva D, Qarshieva D, Davranov K (2004) The use of Bradyrhizobium to enhance growth and yield of soybean in calcareous soil in Uzbekistan. Journal of Plant Growth Regulation, 23, 54-57.

Fairhurst T, Lefrog R, Mutert E, Batjies N (1999) The importance, distribution and causes of phosphorus deficiency as a constraint to crop production in the tropics. Agrofor Forum, 9, 2-8.

Fierer N, Lauber CL, Ramirez KS et al. (2012) Comparative metagenomic, phylogenetic and physiological analyses of soil microbial communities across nitrogen gradients. ISME Journal, 6, 1007-1017.

Ge Y, Zhang JB, Zhang LM, Yang M, He JZ (2008) Long-term fertilization regimes affect bacterial community structure and diversity of an agricultural soil in Northern China. Journal of Soils and Sediments, 8, 43-50.

Ge GF, Li ZJ, Zhang J et al. (2009) Geographical and climatic differences in long-term effect of organic and inorganic amendments on soil enzymatic activities and respiration in field experimental stations of China. Ecological Complexity, 6, 421-431. 
Geisseler D, Scow KM (2014) Long-term effects of mineral fertilizers on soil microorganisms - a review. Soil Biology and Biochemistry, 75, 54-63.

Gorfer M, Blumhoff M, Klaubauf S et al. (2011) Community profiling and gene expression of fungal assimilatory nitrate reductases in agricultural soil. ISME Journal, 5, 1771-1783.

Gu Y, Zhang X, Tu S, Lindström K (2009) Soil microbial biomass, crop yields, and bacterial community structure as affected by long-term fertilizer treatments under wheat-rice cropping. European Journal of Soil Biology, 45, 239-246.

Guan SY (1986) Soil Enzyme and Research Method (in Chinese), pp. 274-339. Agriculture Press, Beijing.

Haynes RJ, Naidu R (1998) Influence of lime, fertilizer and manure applications on soil organic matter content and soil physical conditions: a review. Nutrient Cycling in Agroecosystems, 51, 123-137.

He J-Z, Shen J-P, Zhang L-M et al. (2007) Quantitative analyses of the abundance and composition of ammonia-oxidizing bacteria and ammonia-oxidizing archaea of a Chinese upland red soil under long-term fertilization practices. Environmental Microbiology, 9, 2364-2374.

He ZL, Xu MY, Deng Y et al. (2010) Metagenomic analysis reveals a marked divergence in the structure of belowground microbial communities at elevated $\mathrm{CO}_{2}$. Ecology Letters, 13, 564-575.

van der Heijden MGA, Bardgett RD, van Straalen NM (2008) The unseen majority: soil microbes as drivers of plant diversity and productivity in terrestrial ecosystems. Ecology Letters, 11, 296-310.

Iovieno P, Morra L, Leone A, Pagano L, Alfani A (2009) Effect of organic and mineral fertilizers on soil respiration and enzyme activities of two Mediterranean horticultural soils. Biology and Fertility of Soils, 45, 555-561.

Islam M, Singh Chauhan P, Kim Y, Kim M, Sa T (2011) Community level functional diversity and enzyme activities in paddy soils under different long-term fertilizer management practices. Biology and Fertility of Soils, 47, 599-604.

Jenkinson DS (1988) The determination of microbial biomass carbon and nitrogen in soil. In: Advances in Nitrogen Cycling in Agricultural Ecosystems (ed. Wilson JR), pp. 368-386. C. A. B. International, Wallingford.

Kandeler E (1995a) Nitrate reductase activity. In: Methods in Soil Biology (eds Schinner F, Öhlinger R, Kandeler E, Margesin R), pp. 176-179. Springer, Berlin.

Kandeler E (1995b) Urease activity by colorimetric technique. In: Methods in Soil Biology (eds Schinner F, Öhlinger R, Kandeler E, Margesin R), pp. 171-174. Springer, Berlin.

Kindt R, Coe R (2005) Tree Diversity Analysis. A Manual and Software for Common Statistical Methods for Ecological and Biodiversity Studies. World Agroforestry Centre (ICRAF), Nairobi.

Lan Z, Lin X, Wang F, Zhang H, Chen C (2012) Phosphorus availability and rice grain yield in a paddy soil in response to long-term fertilization. Biology and Fertility of Soils, 48, 579-588.

Lentendu G, Wubet T, Chatzinotas A et al. (2014) Effects of long-term differential fertilization on eukaryotic microbial communities in an arable soil: a multiple barcoding approach. Molecular Ecology, 23, 3341-3355.

Lin X, Feng Y, Zhang $\mathrm{H}$ et al. (2012) Long-term balanced fertilization decreases arbuscular mycorrhizal fungal diversity in an arable soil in North China revealed by 454 pyrosequencing. Environmental Science \& Technology, 46, 5764-5771.

Lu M, Yang Y, Luo Y et al. (2011) Responses of ecosystem nitrogen cycle to nitrogen addition: a meta-analysis. New Phytologist, 189, 1040-1050.

Lu Z, Deng Y, Van Nostrand JD et al. (2012) Microbial gene functions enriched in the Deepwater Horizon deep-sea oil plume. ISME Journal, 6, 451-460.

Majumder B, Mandal B, Bandyopadhyay PK, Chaudhury J (2007) Soil organic carbon pools and productivity relationships for a 34 year old rice-wheat-jute agroecosystem under different fertilizer treatments. Plant and Soil, 297, 53-67.

Manzoni S, Jackson RB, Trofymow JA, Porporato A (2008) The global stoichiometry of litter nitrogen mineralization. Science, 321, 684-686.

Marschner P, Kandeler E, Marschner B (2003) Structure and function of the soil microbial community in a long-term fertilizer experiment. Soil Biology \& Biochemistry, 35, 453-461.

McMurdie PJ, Holmes S (2013) Phyloseq: An R package for reproducible interactive analysis and graphics of microbiome census data. PLoS ONE, 8, e61217.

Mersi WV, Schinner F (1995) CM-cellulase activity. In: Methods in Soil Biology (eds Schinner F, Öhlinger R, Kandeler E, Margesin R), pp. 190-193. Springer, Berlin.

Nemergut DR, Townsend AR, Sattin SR et al. (2008) The effects of chronic nitrogen fertilization on alpine tundra soil microbial communities: implications for carbon and nitrogen cycling. Environmental Microbiology, 10, 3093-3105.

Ng EL, Patti AF, Rose MT et al. (2014a) Functional stoichiometry of soil microbial communities after amendment with stabilised organic matter. Soil Biology \& Biochemistry, 76, 170178

Ng EL, Patti AF, Rose MT et al. (2014b) Does the chemical nature of soil carbon drive the structure and functioning of soil microbial communities? Soil Biology \& Biochemistry, 70, 54 61.

Ogilvie LA, Hirsch PR, Johnston AWB (2008) Bacterial diversity of the Broadbalk 'classical' winter wheat experiment in relation to long-term fertilizer inputs. Microbial Ecology, 56, 525-537.

Oksanen J, Blanchet FG, Kindt R et al. (2012) vegan: Community ecology package. 2.0-4 ed, vol. R package.

Price MN, Dehal PS, Arkin AP (2009) FastTree: computing large minimum evolution trees with profiles instead of a distance matrix. Molecular Biology and Evolution, 26, 1641-1650.

Ramirez KS, Craine JM, Fierer N (2012) Consistent effects of nitrogen amendments on soil microbial communities and processes across biomes. Global Change Biology, 18, 1918-1927.

Roberts DW (2012) labdsv: Ordination and multivariate analysis for ecology. $\mathrm{R}$ package version 1.5-0 ed.

Saunders OE, Fortuna A-M, Harrison JH et al. (2012) Gaseous nitrogen and bacterial responses to raw and digested dairy manure applications in incubated soil. Environmental Science \& Technology, 46, 11684-11692.

Schmidt EL, Belser LW (1994) Autotrophic nitrifying bacteria. In: Methods of Soil Analysis. Part 2: Microbiological and Biochemical Properties (eds Weaver RW, Angle S, Bottomley P et al.), pp. 171-172. Soil Science Society of America, Madison, Wisconsin.

Shang QY, Ling N, Feng XM et al. (2014) Soil fertility and its significance to crop productivity and sustainability in typical 
agroecosystem: a summary of long-term fertilizer experiments in China. Plant and Soil, 381, 13-23.

Simek M, Makarova NM, Santruckova H, Azarova TS (1993) The influence of potassium fertilization on microorganisms in the soil under spring barley. Rostlinna Vyroba, 39, 193-202.

Tabatabai MA (1994) Soil enzymes. In: Methods of Soil Analysis. Part 2: Microbiological and Biochemical Properties (eds Weaver RW, Angle S, Bottomley P et al.), pp. 775-833. Soil Science Society of America, Madison, Wisconsin.

Tiedje JM (1994) Denitrifiers. In: Methods of Soil Analysis. Part 2: Microbiological and Biochemical Properties (eds Weaver RW, Angle S, Bottomley P et al.), pp. 256-257. Soil Science Society of America, Madison, Wisconsin.

Wang QK, Wang SL, Liu YX (2008) Responses to N and P fertilization in a young Eucalyptus dunnii plantation: microbial properties, enzyme activities and dissolved organic matter. Applied Soil Ecology, 40, 484-490.

Wessén E, Hallin S, Philippot L (2010) Differential responses of bacterial and archaeal groups at high taxonomical ranks to soil management. Soil Biology and Biochemistry, 42, 1759-1765.

Wright E (2012) DECIPHER: database enabled code for ideal probe hybridization employing $\mathrm{R}$. $\mathrm{R}$ package version 1.4.0 ed.

Wu J, Joergensen RG, Pommerening B, Chaussod R, Brookes PC (1990) Measurement of soil microbial biomass C by fumigation extraction - an automated procedure. Soil Biology $\mathcal{E}$ Biochemistry, 22, 1167-1169.

Wu J, He ZL, Wei WX, O'Donnell AG, Syers JK (2000) Quantifying microbial biomass phosphorus in acid soils. Biology and Fertility of Soils, 32, 500-507.

Wu MN, Qin HL, Chen Z, Wu JS, Wei WX (2011) Effect of long-term fertilization on bacterial composition in rice paddy soil. Biology and Fertility of Soils, 47, 397-405.

Yang Y, Wu L, Lin Q et al. (2013) Responses of the functional structure of soil microbial community to livestock grazing in the Tibetan alpine grassland. Global Change Biology, 19, 637-648.

Yang Y, Quensen J, Mathieu J et al. (2014) Pyrosequencing reveals higher impact of silver nanoparticles than $\mathrm{Ag}^{+}$on the microbial community structure of activated sludge. Water Research, 48, 317-325.

Yao HY, Bowman D, Rufty T, Shi W (2009) Interactions between $\mathrm{N}$ fertilization, grass clipping addition and $\mathrm{pH}$ in turf ecosystems: implications for soil enzyme activities and organic matter decomposition. Soil Biology \& Biochemistry, 41, $1425-1432$.

Zhang H, Sekiguchi Y, Hanada S et al. (2003) Gemmatimonas aurantiaca gen. nov., sp nov., a gram-negative, aerobic, polyphosphate-accumulating micro-organism, the first cultured representative of the new bacterial phylum Gemmatimonadetes phyl. nov. International Journal of Systematic and Evolutionary Microbiology, 53, 1155-1163.

Zhang J, Müller C, Zhu T, Cheng Y, Cai Z (2011) Heterotrophic nitrification is the predominant NO 3 - production mechanism in coniferous but not broad-leaf acid forest soil in subtropical China. Biology and Fertility of Soils, 47, 533-542.

Zhang Q-C, Shamsi IH, Xu D-T et al. (2012) Chemical fertilizer and organic manure inputs in soil exhibit a vice versa pattern of microbial community structure. Applied Soil Ecology, $57,1-8$.

Zhong WH, Cai ZC (2007) Long-term effects of inorganic fertilizers on microbial biomass and community functional diver- sity in a paddy soil derived from quaternary red clay. Applied Soil Ecology, 36, 84-91.

Zhou J, Bruns MA, Tiedje JM (1996) DNA recovery from soils of diverse composition. Applied and Environmental Microbiology, 62, 316-322.

Zhou J, Wu L, Deng Y et al. (2011) Reproducibility and quantitation of amplicon sequencing-based detection. ISME Journal, 5, 1303-1313.

Zhou J, Xue K, Xie J et al. (2012) Microbial mediation of carbon-cycle feedbacks to climate warming. Nature Climate Change, 2, 106-110.

Zhou J, Jiang Y-H, Deng Y et al. (2013) Random sampling process leads to overestimation of $\beta$-diversity of microbial communities. MBio, 4, e00324-00313.

Y.G.Z. designed the experiment. J.Q.S. and L.J.D. performed soil sampling. W.X.W. and J.S.W. managed the long-term fertilization field. L.J.D. performed soil chemical and biological parameters analysis. J.Q. performed 16S rRNA gene pyrosequencing and conducted bioinformatic and statistical analysis. S.J.B. performed GEOCHIP experiment, and J.Q.S. and K.X. conducted statistical analysis. J.Q.S., L.J.D. and H.Y.Y. wrote the manuscript with editorial remarks from J.Z. and J.M.T. and advice from all co-authors.

\section{Data accessibility}

DNA sequences: NCBI SRA: SRP043656.

Aligned sequences, OTU table, R code and input files for analysis of 16S rRNA gene: Dyrad doi:10.5061/ dryad.t64s0.

$\mathrm{R}$ code and input files for analysis of GEOCHIP data: Dyrad doi:10.5061/dryad.t64s0.

\section{Supporting information}

Additional supporting information may be found in the online version of this article.

Table S1 Pearson's correlation between soil properties and rice yield.

Fig. S1 Ordination plot produced from principal-component analysis (PCA) of geochemical data for all the samples.

Fig. S2 Average rice yields over 5 years from 2005 to 2009 in the long-term fertilization experiments.

Fig. S3 Average percentages of total 16S rRNA gene sequences classified to each phylum for each treatment.

Fig. S4 Twenty-five most abundant OTUs in the samples.

Fig. S5 (A) chao1 estimators showing the phylogenetic diver- 
sity of bacterial community of all the samples. (B) Renyi diversity profiles by treatment.

Fig. S6 (A) Ordination plot produced from principal coordinates analysis (PCoA) of 16S rRNA gene based pyrosequencing data. (B) Principal components analysis of Hellinger transformed OTU counts based on 16S rRNA gene based pyrosequencing data.

Fig. S7 Correlations between sequence abundances and available phosphorus.

Fig. S8 Diversity (inverse simpson) of functional genes.
Fig. S9 The relative changes of the detected genes involved in the N cycle (Control vs. NPK treatment)

Fig. S10 The relative changes of the detected genes involved in the $\mathrm{N}$ cycle (Control vs. $\mathrm{N}$ treatment).

Fig. S11 The normalized average signal intensity of the detected key functional genes involved in P cycling.

Fig. S12 The normalized average signal intensity of the detected functional genes involved in methane metabolism. 